\title{
Van-e esélyük a feljutó csapatoknak a bennmaradásra?
}

\section{Az európai labdarúgó-bajnokságok összehasonlítása az első osztály elönye alapján}

Az európai országokban hierarchikus rendszerben müködnek a labdarúgó-bajnokságok: az osztályok között kieséssel és feljutással mozognak a csapatok. Tanulmányunkban három mutatószám segítségével számszerüsítjük az első osztály előnyét a másodosztállyal szemben az első osztályba feljutó csapatok teljesítményének mérésével. Az első mutató a feljutó csapatok bennmaradási arányát, míg a másik két mutatószám a feljutó csapatok által szerzett mérkőzésenkénti pontszámot viszonyítja a bennmaradáshoz szükséges értékhez. A számításokat 21 európai labdarúgóliga historikus adataira végezzük el. A 2007/2008 és a 2016/2017 közötti szezonok alapján a legnépszerübb bajnokságok közül Franciaországban és Angliában a legnagyobb, Németországban pedig a legkisebb az első osztály fölénye. A különbségek gazdasági okait megvizsgálva, a magyar újoncok átlagosnál jobb teljesítményét a kiesés és feljutás csekély pénzügyi vonzata okozhatja, míg az angol újoncok a pénzügyi kockázatok miatt nem motiváltak erőfeszítéseket tenni a bennmaradás érdekében. Végül, a mutatószámok értékei alapján javaslatokat teszünk a ligák átalakítására a versenyegyensúly figyelembevételével. ${ }^{*}$

Journal of Economic Literature (JEL) kód: Z20, L83.

Az európai labdarúgásban a klubok általában nemzetek szerinti bontásban, hierarchikus ligákban versenyeznek egymással. Ez azt jelenti, hogy van egy legfelső csoport (első osztály, élvonal), amely az adott nemzet aktuálisan legerősebb

* A szerzők köszönettel tartoznak a Magyar Közgazdaságtudományi Egyesületnek, hogy konferenciáján lehetővé tették a tanulmány korábbi változatának bemutatását. A szerzők hálával tartoznak Kehl Dánielnek, Petróczy Dóra Grétának és Csató Lászlónak a tanulmány korábbi változatához füzött hasznos megjegyzéseikért, valamint az anonim lektoroknak, akik észrevételeikkel növelték a tanulmány színvonalát. A kutatás az Innovációs és Technológiai Minisztérium ÚNKP-20-3-II kódszámú Új Nemzeti Kiválóság Programjának szakmai támogatásával, valamint az EFOP-3.6.3VEKOP-16-2017-00007 („Tehetségből fiatal kutató - A kutatói életpályát támogató tevékenységek a felsőoktatásban”) projekt támogatásával készült.

Gyimesi András, PTE Közgazdaságtudományi Kar, Regionális Politika és Gazdaságtan Doktori Iskola (e-mail: gyimesi.andras@ktk.pte.hu).

Braun Erik, ELKH KRTK Regionális Kutatások Intézete; PTE Közgazdaságtudományi Kar, Regionális

Politika és Gazdaságtan Doktori Iskola (e-mail: braun.erik@krtk.hu).

A kézirat első változata 2021. január 27-én érkezett szerkesztőségünkbe.

DOI: http://dx.doi.org/10.18414/KSZ.2021.7-8.863 
klubcsapatait tömöríti. A hierarchiában e szint alatt helyezkedik el a nemzet második ligája (másodosztály), valamint léteznek a nemzet méretétől és a csapatok létszámától függően további országos és regionális osztályok, amelyek a hierarchia alacsonyabb szintjeinek felelnek meg. Magyarországon például jelenleg három országos és három-négy regionális szint működik. Az európai labdarúgás esetében a legfelső szinten kizárólag egy első osztály található, azonban az alacsonyabb, főként regionális szinteken párhuzamosan több liga is működik, amelyek azonos hierarchikus szinten helyezkednek el. Magyarország esetében a legfelső szintet egy liga képviseli, azonban például a legfelső regionális szinten több, azonos hierarchikus szinten lévő liga (megyei első osztály) is müködik.

Az európai labdarúgásra és általában az európai csapatsportokra jellemző a csapatok osztályok közötti vertikális mozgása, amit a feljutásos/kieséses rendszer hordoz magában. A szezon végén az adott szintű liga legjobb csapatai feljutnak a hierarchián eggyel feljebb lévő ligába, míg a legrosszabbul teljesítő csapatok ezzel párhuzamosan eggyel kisebb szintü ligába esnek ki. A hierarchia legalsó szintjén található ligákból nem lehet kiesni, valamint a legfelső osztályból sem lehet egy még magasabb osztályba feljutni. Az ilyen rendszerben müködő bajnokságokat a szakirodalom nyitottnak nevezi (Andreff [2011], Buzzacchi és szerzötársai [2010]). Emellett azonban léteznek zárt bajnokságok is, amelyek elsősorban az észak-amerikai csapatsportokra jellemzők. A zárt bajnokságok sajátossága, hogy franchise-rendszerben müködnek, a csapatok összetétele állandó, nincs kiesés és feljutás, így alsóbb osztályok sem léteznek. Egy ilyen típusú bajnokság csapatainak külső versenyt csak egy másik rivális bajnokság megalakulása jelenthet. Ezzel szemben az európai labdarúgó-bajnokságokat müködtető szervezetek az Európai Labdarúgó-szövetség (Union of European Football Associations, UEFA) felügyelete alá tartoznak, amely kizárja a hierarchián kívüli, rivális ligák létrejöttét. A nyílt és a zárt bajnokságok müködésében számos más különbség is található, amelyekről részletes leírások olvashatók a szakirodalomban (Andreff [2011], Hoehn-Szymanski [1999], Ross-Szymanski [2002]).

Nyílt típusú bajnokságok esetén a feljutásos/kieséses rendszer miatt az első osztályú csapatokra nyomást gyakorolnak a másodosztályból feljutó csapatok, hiszen a feljutó csapatok kiszoríthatják a legfelső szintről a korábban ott lévő csapatokat. A tanulmányban feljutó - más néven újonc - csapatokon azokat az első osztályú csapatokat értjük, amelyek az adott szezont megelőző szezonban nem voltak az első osztály tagjai, és a másodosztályban szerepeltek. Kieső csapatokon azokat a csapatokat értjük, amelyek az adott évben az első osztály tagjai voltak, viszont a következőben már nem. Ha a feljutó csapatok jó eredményekre képesek az első osztályban, az arra utal, hogy az első és a másodosztály között nincs jelentős teljesítménybeli különbség. Ilyenkor az első osztályban élesebb a tagság megőrzéséért folytatott verseny, és nagyobb az első osztályú csapatokra nehezedő nyomás. Így az újonc csapatok teljesítményének mérésével számszerüsíthető egyrészt az első osztály előnye a másodosztállyal szemben, másrészt az első osztályú csapatokra nehezedő nyomás mértéke.

Az 1. táblázat a legnépszerủbb európai bajnokságok (top 5) 2016/2017-es szezonjának eredményeit mutatja be, méghozzá az újonc csapatok első osztályban elért teljesítménye alapján. 
1. táblázat

Az öt legnépszerübb európai bajnokság újoncainak teljesítménye a 2016/2017-es szezonban

\begin{tabular}{llccc}
\hline Ország & Újonc csapat & Helyezés & Pontszám & $\begin{array}{c}\text { Bennmaradástól } \\
\text { vett távolság (pont) }\end{array}$ \\
\hline Németország & SC Freiburg & 6. & 48 & 11 \\
& RB Leipzig & 2. & 67 & 30 \\
\hline Anglia & Burnley & 16. & 40 & 0 \\
& Middlesbrough & 19. & 34 & -6 \\
& Hull City & 18. & 28 & -12 \\
\hline Spanyolország & Alavés & 9. & 55 & 20 \\
& CD Leganés & 17. & 35 & 0 \\
& CA Osasuna & 19. & 22 & -13 \\
\hline Olaszország & Cagliari Calcio & 11. & 47 & 0 \\
& Crotone & 17. & 34 & -16 \\
\hline Franciaország & Aescara & 20. & 18 & -2 \\
& AS Nancy & 19. & 35 & 0 \\
& Dijon & 16. & 37 & 7 \\
\hline
\end{tabular}

Forrás: saját szerkesztés a www.worldfootball.net weboldal adatai alapján.

A táblázatban látható, hogy a német Bundesliga két újonc csapata igen elökelő helyen végzett, azonban az angol Premier League három újonca közül csak a Burnley csapatának sikerült kiharcolni a bennmaradást, amely alakulat a 16. helyen végzett, és szintén közel volt a kieséshez. A spanyol és az olasz első osztályban (La Liga, Serie A) a feljutó csapatok közül egy a középmezőnyben végzett, egy épphogy bent tudott maradni, egy pedig kiesett az első osztályból. A francia élvonalban (Ligue 1) szereplő három újonc csapat közül kettőnek sikerült megőrizni első osztályú tagságát, azonban ezek a csapatok is a tabella utolsó harmadában végeztek. Az újonc csapatok bennmaradási arányát tekintve például jól látható, hogy a Bundesliga újoncai jobban teljesítettek a többi nemzet feljutóihoz képest, míg a spanyol és olasz első osztály csapatai azonos eredményt értek el, mindkét esetben két-két csapat őrizte meg élvonalbeli tagságát. A táblázat harmadik, negyedik és ötödik oszlopa azonban árnyalja a képet. Ezek alapján úgy tünik, hogy például a spanyol újonc csapatok jobban teljesítettek az olaszok újoncoknál, hiszen a legrosszabbul teljesítő CA Osasuna a 19. helyen végzett, 13 ponttal lemaradva a még bennmaradást érö helyezéstől, míg az olasz Pescara az utolsó, a 20. helyen végzett, 16 ponttal lemaradva a bennmaradástól. A két első osztály legjobb újoncai (Alavés és Cagliari) között is hasonló különbségek figyelhetők meg. Ez a példa rávilágít arra, hogy az újonc csapatok teljesítményének meghatározása többféleképpen is történhet. A 2016/2017-es szezon eredményei arra utalnak, hogy jelentős különbségek lehetnek a bajnokságok között, azonban az egyes nemzetek összehasonlítása nem egyértelmü feladat, különösen abban az esetben, ha a nemzetek 
első osztályaiban eltérő számú csapat szerepel, valamint eltérő számú csapat jut fel, illetve esik ki.

Tanulmányunkban három különböző módszerrel vizsgáljuk meg, hogy valójában mekkora nyomást képesek helyezni a másodosztályból feljutó csapatok az első osztályban bennmaradó csapatokra, azaz milyen mértékben képesek megörizni élvonalbeli tagságukat a feljutó csapatok. Amennyiben a feljutó csapatok jól teljesítenek, úgy magas nyomást helyeznek a korábban is az élvonalban szereplö csapatokra, amelyeknek ezáltal jóval nehezebb megörizni élvonalbeli tagságukat. Ezzel szemben, ha az újoncok rosszul teljesítenek, akkor a nyílt bajnokságok céljával ellentétben nincs valódi nyomás az első osztályú klubokon, és hosszú távon stabilizálódik az első ligában szereplők köre, hasonlóan egy zárt rendszerü bajnoksághoz. Az elemzéseket 21 európai bajnokságra végezzük el, valamint az adatok rendelkezésre állásától függően a feljutó csapatok teljesítményének időbeli alakulását is megvizsgáljuk.

Tanulmányunk a következőképpen épül fel. Elöször a nyílt típusú bajnokságokat és ennek következményeit közgazdasági szemszögből vizsgáló szakirodalmat mutatjuk be, majd az elemzéshez felhasznált adatokat és módszertani eszközöket ismertetjük részletesen. Ezt követően felvázoljuk az európai bajnokságok első osztályaiban szereplö újonc csapatok teljesítményét, illetve bemutatjuk a magyar és az angol első és másodosztályú csapatok pénzügyi hátterét, amely egy lehetséges magyarázatot nyújt az élvonalba feljutó csapatok teljesítményére vonatkozóan. A tanulmányt az eredmények rövid összegzésével és a bajnokságok átalakítására vonatkozó javaslatainkkal zárjuk.

\section{Szakirodalmi áttekintés}

Kérdésfelvetésünk újszerü abból a szempontból, hogy a szakirodalomban nem található expliciten a hierarchikus ligák közötti átmenetet vizsgáló nemzetközi összehasonlító elemzés. Az európai bajnokságokra jellemző feljutásos/kieséses rendszer gazdasági következményeit számos korábbi tanulmány vizsgálja (Andreff [2011], Buzzacchi és szerzötársai [2010], Goddard [2014], Jasina-Rotthoff [2012], Noll [2002], Szymanski-Valletti [2010]). Jóléti szempontból a feljutásos/ kieséses rendszer megítélése vegyes. Gyakran egy kisebb piacon mozgó csapat szerepelhet az első osztályban egy nagyobb piacon mozgó rovására, ami a nem optimális allokáció miatt jóléti veszteséghez vezet (Noll [2002]). Ugyanakkor a kiesés elkerülése egy addicionális tétet jelent, így a középmezőny csapatait is jobb teljesítményre ösztönzi, még akkor is, ha már nincs esélyük elérni az elökelö pozíciókat (Jasina-Rotthoff [2012], Szymanski-Valletti [2010]). A kiesés elkerüléséből fakadó erősebb ösztönzés a zárt ligákhoz képest magasabb költésekre és játékosvásárlásra ösztönöz, azonban csökkenti a klubok profitját. Ez összességében emeli a bajnokság átlagos színvonalát, ami jóléti szempontból kedvező (Jasina-Rotthoff [2012], Szymanski-Valletti [2010]).

Noll [2002] az angol bajnokság adatait vizsgálva azt találta, hogy a feljutás bevétel- és nézettségnövekedéssel jár a csapatok számára, míg a kieséssel járó csökkenés 
ezen tényezőket tekintve kisebb mértékủ. A feljutás haszna tehát permanens bevételnövekedést okoz, még a feljutást követő gyors kiesés esetén is, így a csapatok ösztönözve vannak a feljutásra, azonban a bennmaradás már kevésbé motiválja őket. Az angol bajnokság 1990-es éveiben így több kisebb piacon mozgó csapat is a feljutás kivívása érdekében tett jelentős ráfordításokat - például játékosvásárlásokon keresztül - a bennmaradás kiharcolásával szemben. Ez a magatartás rontja a feljutó csapatok versenyképességét az első osztályban, növelve ezzel a korábbi élvonalbeli klubok előnyét. Goddard [2014] szintén az angol élvonalat vizsgálva mutatja be, hogy 1920 óta folyamatosan növekedett azon feljutó csapatok aránya, amelyek az első évükben ki is estek, miközben a kieső csapatok egyre kisebb arányban tudtak visszajutni az élvonalba a kiesést követő szezonban. Ezek a trendek olyan szituációhoz vezettek a 2000-es évekre, amelyben a Premier League csapatainak nagy része állandó maradt, míg a leggyengébb néhány csapat folyamatosan cserélődött. A szerző kiemeli, hogy a 2000-es évekre jelentős pénzügyi különbségek is kialakultak az angol első és másodosztályú klubok között, aminek fö oka, hogy az egyre növekvő közvetítési bevételek kizárólag az első osztályban jelentek meg.

Dherbecourt-Drut [2009] tanulmánya a kiesési és feljutási esélyek empirikus modellezésével foglalkozik, amelyben a szerzők számos változó bevonásával egy logit regressziós modellt állítanak fel a kiesés és a feljutás előrejelzésére. A top 5 európai liga adatait elemzik, azonban nem térnek ki a ligák közötti különbségekre. Tanulmányok egy másik csoportja szervezeti ökológiai nézőpontból elemzi a klubok túlélését az első osztályú ligákban (Celik [2019], Chang és szerzőtársai [2019], Frick-Wallbrecht [2012], Oberhofer és szerzötársai [2015]). Az eredmények arra mutatnak rá, hogy e bajnokságok müködése nagyon hasonló egy általános piachoz, ugyanis a feljutó csapatok esélye a bennmaradásra hasonlóan alacsony, mint az újonnan alakult vállalatok piacra lépése és hosszú távú fennmaradása. A korábbi kutatások tehát összességében arra utalnak, hogy a feljutásos/kieséses rendszer ellenére az élvonalba történő belépési korlát erős, és az első osztályú csapatok kiléte viszonylag állandó. Jelen tanulmány a szakirodalmat kiegészítve rámutat az egyes bajnokságok közötti különbségekre, amelyek részben gazdasági okokra vezethetők vissza.

Vizsgálatainkhoz szintén kapcsolódik a sportgazdaságtan nemzetközi szakirodalmának egyik központi kérdése, a sportverseny egyensúlya (competitive balance) is. A ligák rendszerint célként tüzik ki a versenyegyensúly növelését, mivel szükség van a bajnokság kimenetelének bizonytalanságára, hogy a verseny érdekes maradjon a szurkolók számára (Szymanski [2003]). A versenyegyensúly és a nézettség közötti kapcsolatot empirikus bizonyítékok is alátámasztják. A csapatok eredményeinek változatossága (dinamikus versenyegyensúly) szignifikánsan növelte az átlagos helyszíni nézettséget az európai első osztályú labdarúgó-bajnokságokban (Gyimesi [2020]), valamint az amerikai baseballbajnokságban (Humphreys [2002], Krautmann-Hadley [2006]). Buzzacchi és szerzötársai [2010] megmutatja, hogy a dinamikus versenyegyensúly historikusan magasabb az észak-amerikai zárt ligákban, mint az európai labdarúgásban. Ez azt jelenti, hogy a feljutásos/kieséses rendszer ellenére hosszabb időszakon keresztül nem tudott több csapat az elökelö 
pozíciókban végezni. Ez a különbség azzal magyarázható, hogy az észak-amerikai ligákban nagyobb mértékű a csapatok között a bevételek redisztribúciója, valamint számos egyéb verseny-kiegyensúlyozó intézkedést - mint például a fizetési plafont vagy a draftrendszert - alkalmaznak (Buzzacchi és szerzőtársai [2010]). Ennek fö magyarázata, hogy a zárt ligákban a csapatok a kiesés fenyegetése nélkül jobban ösztönözve vannak a bevételek és egyéb eröforrások megosztására (SzymanskiValletti [2010]). Az európai labdarúgásban is használják a bevételek redisztribúcióját a versenyegyensúly érdekében (Kesenne [2006]), azonban az újraosztás nagy része az első osztályú bajnokságokon belül történik. Például az angol élvonalat érintő 1992-es változtatás óta a közvetítési bevételek korábbiaknál kisebb hányadát osztják szét szolidaritási alapon a legutóbbi három szezon élvonalból kieső csapatai között (Goddard [2014]). Az ilyen csapatokhoz juttatott források a 2017/2018as szezonban a közvetítési bevételek 5,7 százalékát tették ki. A bevételmegosztási struktúra tehát a versenyegyensúly mellett jelentősen befolyásolhatja az első osztály előnyét is az egyes országokban.

A szakirodalomban széles körben végezték el az európai bajnokságok versenyegyensúly szerinti összehasonlítását különböző koncentrációs mutatószámok segítségével (Buzzacchi és szerzötársai [2010], Fürész-Rappai [2018], Goossens [2006], Haan és szerzötársai [2007], Manasis-Ntzoufras [2014], Michie-Oughton [2004], Pawlowski és szerzőtársai [2010]), azonban ezek a tanulmányok kizárólag az első osztályra térnek ki. Egy olyan bajnokság, ahol az első osztály előnye kisebb, és a feljutó csapatok is versenyképesek, kiszámíthatatlanabb, és ezáltal érdekesebb lehet a nézők számára. Így az első osztályú klubokra nehezedő nyomást számszerüsítő elemzésünk a versenyegyensúly mérésével foglalkozó kutatásokhoz is hozzájárulhat.

A következőkben az elemzésekhez felhasznált adatokat és a feljutó csapatok teljesítményét mérö módszereket ismertetjük.

\section{Felhasznált adatok és módszertan}

\section{Felhasznált adatok}

Az empirikus elemzés során felhasznált adatállomány 21 európai ország első osztályú labdarúgó-bajnokságának végeredményeit tartalmazza a 2017/2018-as szezonig bezárólag. A kezdő szezon időpontja az adatok rendelkezésre állása miatt országonként eltérő, ahogy az a 2. táblázatban is látható. Minden ország esetében a kezdő szezont csupán arra használjuk fel, hogy azonosítsuk az azt követő szezon újonc csapatait. Ebböl egyben az is következik, hogy az utolsó szezon is csak annak megállapítására szolgál, hogy vajon sikerült-e kiharcolni a feljutó csapatoknak a bennmaradást, vagy sem. Az adatok forrása a www.worldfootball.net weboldal, ahol a szezonok végeredményei nyilvánosan rendelkezésre állnak. Az adatállomány minden csapatszezon megfigyeléshez információt nyújt arról, hogy melyik bajnokságban vett részt, milyen helyezést és pontszámot ért el, valamint egyéb eredményességi mutatókat is - mint például a lőtt gólok száma - tartalmaz. 
2. táblázat

Az elemzés során felhasznált, első osztályú ligákra vonatkozó általános információk

\begin{tabular}{|c|c|c|c|}
\hline \multirow[t]{3}{*}{ Ország } & \multirow[t]{3}{*}{ Kezdő szezon } & \multicolumn{2}{|c|}{ A csapatok } \\
\hline & & minimális & maximális \\
\hline & & \multicolumn{2}{|c|}{ száma } \\
\hline Anglia & $1956 / 1957$ & 20 & 22 \\
\hline Ausztria & $1974 / 1975$ & 10 & 16 \\
\hline Belgium & $1960 / 1961$ & 16 & 20 \\
\hline Csehország & 1993/1194 & 16 & 16 \\
\hline Dánia & $1991 / 1992$ & 10 & 14 \\
\hline Franciaország & $1956 / 1957$ & 18 & 20 \\
\hline Görögország & $1994 / 1995$ & 14 & 18 \\
\hline Hollandia & $1957 / 1958$ & 16 & 18 \\
\hline Horvátország & $1992 / 1993$ & 10 & 18 \\
\hline Magyarország & 1993/1994 & 12 & 18 \\
\hline Németország* & $1963 / 1964$ & 16 & 20 \\
\hline Norvégia & $1962 / 1963$ & 10 & 16 \\
\hline Olaszország & $1956 / 1957$ & 16 & 20 \\
\hline Oroszország & 1993/1994 & 16 & 18 \\
\hline Portugália & $1956 / 1957$ & 14 & 20 \\
\hline Románia & $1956 / 1957$ & 12 & 18 \\
\hline Skócia & $1956 / 1957$ & 10 & 18 \\
\hline Spanyolország & $1956 / 1957$ & 16 & 22 \\
\hline Svájc & $1977 / 1978$ & 10 & 16 \\
\hline Svédország & $1959 / 1960$ & 10 & 16 \\
\hline Szerbia & $2003 / 2004$ & 12 & 16 \\
\hline
\end{tabular}

* Németország újraegyesítése előtt az NSZK Bundesliga bajnokságát vettük figyelembe. Ennek a folytatása a mai Bundesliga.

Forrás: saját szerkesztés a www.worldfootball.net weboldal adatai alapján.

Fontos megjegyezni, hogy az egyes országok első osztályaiban különböző számú csapat vesz részt, és ez akár időben is változhat. Emiatt a 2. táblázatban feltüntettük az adott bajnokságban szereplő csapatok maximális és minimális számát is a vizsgált időszak alatt. Az olyan években, amikor egy bajnokságot bővítenek, a másodosztályból feljutók számát megemelik, így töltik fel az első osztály megnövekedett létszámát. Emellett jellemzően ekkor is kiesnek az első osztályból a kieső pozíciókban végző csapatok. Példaként, a magyar Nemzeti Bajnokságot 2004-ben 12-ről 16 csapatosra bővítették, így a 2003/2004-es szezon után egy csapat kiesett, míg öt csapat jutott fel az első osztályba a következő szezonra. Ennek a fordított esetére, az első osztály létszámának csökkentésére is találunk példát a magyar bajnokságban. 2015-ben újra 
lecsökkentették a létszámot 16-ról 12-re, aminek következtében a két feljutó csapat mellett hat csapat is kiesett a 2015/2016-os szezonra.

Több ország esetében - mint például Belgium és Dánia - az első osztályú szezont két részre lehet osztani: egy alapszakaszra és egy rájátszásra. Elöbbi esetében minden csapat megmérkőzik egymással, majd az ezen mérkőzések alapján kialakult eredmények szerint a ligában részt vevő csapatokat két részre osztják. A jobban teljesítő csapatok a felsőházba kerülnek, amelyek a bajnoki címért küzdenek, míg a rosszabbul teljesítö klubok az alsóházban próbálják meg elkerülni a kiesést. A szezon ezen szakaszában a felső- és alsóházban lévő csapatok nem mérkőznek meg egymással. Az újonc csapatok teljesítményének mérésekor kizárólag az alapszakasz eredményeit vesszük figyelembe, ugyanis csak így hasonlíthatók össze az egyes országok. Amennyiben egy újonc csapat az alsóházba kerül az alapszakaszban elért teljesítménye szerint, akkor a rájátszásban már csak a kevésbé jól teljesítő csapatokkal fog megmérkőzni, és nagyobb esélye van több pontot begyüjteni egy rájátszás nélküli liga újonc csapataihoz képest. $\mathrm{Az}$ ehhez hasonló torzítások miatt figyelmen kívül hagyjuk a rájátszás eredményeit.

\section{Alkalmazott módszertan}

Az egyes országok első osztályában szereplő újonc csapatok teljesítményének mérése és összehasonlítása nehéz feladat, hiszen az élvonalbeli ligák lebonyolítási rendszere igen sokszínű. Az első osztályokban különböző számú csapat szerepel, valamint a feljutó és a kieső csapatok száma is eltérő. Módszertani szempontból szintén nehézséget okoz, hogy a lejátszott mérkőzések számát tekintve is heterogének az első osztályú európai labdarúgóligák. A következőkben három különböző módszert mutatunk be - kezdve a legegyszerübb mutatótól a legbonyolultabb méröszámig -, amelyek segítségével megvizsgálható az újonc csapatok teljesítménye az élvonalbeli tagság megőrzésének szempontjából. Mindhárom mutató sajátossága, hogy ha az újonc csapatok jobban teljesítenek a kiesést illetően - másképpen fogalmazva, kisebb arányban veszítik el első osztályú tagságukat, valamint a kiesési küszöbhöz képest jóval több pontot gyüjtenek -, akkor nagyobb nyomást helyeznek a feljutó csapatok a korábbi első osztályú csapatokra.

A BENNMARADÓ ÚJONCOK ARÁNYA MÓDSZER • Elsőként egy nagyon egyszerü arányszám alapján mérjük meg, hogy a másodosztályból feljutó csapatok milyen mértékủ nyomást tudtak helyezni az első osztályú csapatokra a vizsgált időszakban. A módszer szerint először meghatározzuk az első osztályba feljutó csapatok számát, majd a bajnokság lezárultával megnézzük, hogy hány újonc csapatnak sikerült bennmaradni. Végül a bennmaradó újonc csapatok számát elosztva az újonc csapatok számával kapjuk meg a bennmaradási arányt. Ezt a mutatót Goddard [2014] is használja az angol bajnokság újoncainak teljesítményére vonatkozó történeti elemzésében.

A mutató formai meghatározása a következöképpen írható fel. Tegyük fel, hogy egy adott $c$ ország első osztályú ligájában az adott $t$-edik szezonban $k_{c, t}=1,2, \ldots K_{c, t} c$ sapat szerepel, míg az újonc csapatok számát $n_{c, t}=1,2, \ldots N_{c, t}$ a bennmaradó újonc csapatok 
számát pedig $r_{c, t}=1,2, \ldots R_{c, t}$ jelöli, továbbá fennáll, hogy $K_{c, t} \geq N_{c, t} \geq R_{c, t} \forall c, t$ esetén. Ekkor az előző bekezdésben felvázoltak szerint az újoncok bennmaradási aránya (ratio of retained rookies, $R R R$ ) a következőképpen határozható meg:

$R R R_{c, t}=\frac{R_{c, t}}{N_{c, t}}$.

A mutató abban az esetben veszi fel a maximális $\left(R R R_{c, t}=1\right)$ értéket, ha az adott liga adott szezonjában minden feljutó csapat kiharcolja a bennmaradást. Ezzel szemben a minimális $\left(R R R_{c, t}=0\right)$ értéket akkor veszi fel, ha minden újonc kiesik.

Az 1. táblázatban bemutatott angol példa szerint a 2016/2017-es szezonban három feljutó csapat közül egy tudta megőrizni élvonalbeli tagságát, aminek következtében a mutató értéke $R R R_{\text {angol, 16/17 }}=0,33$. Ehhez képest Németországban mindkét újonc elkerülte a kiesést, ami miatt $R R R_{\text {német, } 16 / 17}=1$. Ezzel a módszerrel tehát egyszerüen és gyorsan megmérhető, hogy egy ország első osztályú csapataira mekkora nyomást helyeznek a másodosztályból feljutó csapatok az adott szezonban. Fontos azonban hangsúlyozni, hogy a módszer figyelmen kívül hagyja a pontos helyezéseket és a helyezések közötti pontkülönbségeket is. A táblázat eredményeit elemezve látható, hogy Spanyolország és Franciaország esetében is két-két újonc csapat tudott bennmaradni, viszont elsősorban az Alavés teljesítménye miatt a spanyol feljutók összességében jobb helyezést értek el. Tehát, amíg ebben a szezonban a két első osztály bennmaradási aránya azonos az újonc csapatokat tekintve $\left(R R R_{\text {spanyol, } 16 / 17}=R R R_{\text {francia, } 16 / 17}=0,67\right.$, addig a helyezéseket is figyelembe véve a spanyol liga feljutó csapatai jelentősen jobban teljesítettek. Hasonló megállapítás tehető a megszerzett pontok tekintetében is. Az Alavés 55 pontot szerezve 20 ponttal többet szerzett a még bennmaradást jelentö 17 . helyen végzett CD Leganés csapatához képest, míg a francia FC Metz csupán 7 ponttal szerzett többet a 17 . helyen végző csapathoz képest. E szempontokat figyelembe véve a következökben egy olyan módszert ismertetünk, amely számításba veszi az elért pontszámokat is a feljutó csapatok teljesítményének meghatározásakor.

Az ÚJONCOK TÁVOLSÁGA A BENNMARADÁSTÓL MÓDSZER • A pontszámok összehasonlításakor kulcsfontosságú, hogy a csapatok hány mérkőzést játszottak le, hiszen több mérkőzés esetén a csapatok által megszerzett pontszám és a közöttük lévő pontbeli különbségek nagyobbak lehetnek. Emiatt a csapatok által elért pontszámokat mérkőzésre levetítve számoljuk ki, tehát azt nézzük meg, hogy a feljutó csapatok egy átlagos mérkőzésen hány pontot szereztek az adott szezonban, majd ezen értékeket viszonyítjuk az utolsó bennmaradó csapat értékéhez.

Egy $c$-edik ország $t$-edik szezonjában az első osztályban játszó $k$-adik csapat pontszámát $x_{k, c, t}$, az első osztályban játszó újonc csapatok pontszámát $y_{n, c, t}$ míg az utolsó bennmaradó csapat pontszámát $z_{c, t}$ jelöli. A vizsgált országokban és szezonokban az egyes ligákhoz tartozó csapatok különböző számú mérkőzést játszottak le, amit a továbbiakban $m_{c, t}$ jelöl. Ekkor az újonc csapatok és az utolsó, még éppen bennmaradó csapat átlagos mérkőzésenkénti pontszáma $\left(\bar{y}_{n, c, t}, \bar{z}_{c, t}\right)$ a (2) szerint írható fel: 
$\bar{y}_{n, c, t}=\frac{y_{n, c, t}}{m_{c, t}} \quad$ és $\quad \bar{z}_{c, t}=\frac{z_{c, t}}{m_{c, t}}$.

Ezt követően az újonc csapatok bennmaradástól való távolságát $\left(d_{n, c, t}\right)$ a következőképpen kapjuk meg:

$d_{n, c, t}=\bar{y}_{n, c, t}-\bar{z}_{c, t}$.

Végül ezeket a távolságokat átlagolva a feljutó csapatok szerint meghatározható az újonc csapatok átlagos távolsága a bennmaradástól (distance from the last retained team, DLRT):

$\operatorname{DLRT}_{c, t}=\frac{\sum_{n=1}^{N} d_{n, c, t}}{N_{c, t}}=\frac{\sum_{1}^{N} \bar{y}_{n, c, t}}{N_{c, t}}-\bar{z}_{c, t}$.

A feljutó csapatok pozitív $d_{n, c, t}$ távolság esetén jobban, míg negatív távolság esetén rosszabbul teljesítettek az utolsó, még bennmaradó csapathoz képest. Ha egy csapat távolsága abszolút értékben nagyobb, akkor a vizsgált csapat távolabb végzett az utolsó bennmaradó csapathoz képest, azaz jelentősen kevesebb vagy több pontot szerzett, attól függően, hogy negatív vagy pozitív értékről van szó. A (4) egyenlet által meghatározott, az összes újoncra vonatkozó átlagos távolság értelmezése is hasonló.

A fenti módszer előnye, hogy pontosabban mérhető meg a feljutó csapatok teljesítménye. Ahogy azt korábban is említettük, a 2016/2017-es szezonban az újonc csapatok bennmaradási aránya megegyezett a spanyol és a francia élvonalban, azonban a távolságalapú mutatószám alkalmazásával már eltérő eredményeket kapunk. A francia élvonalban a Caen 38 mérkőzésen 37 pontot gyüjtve végzett a 17. helyen, ami alapján átlagosan mérkőzésenként $\bar{z}_{\text {francia, } 16 / 17}=0,97$ pontot szerzett. Az újonc AS Nancy $\bar{y}_{\text {nancy,francia, } 16 / 17}=0,92$, a Dijon $\bar{y}_{\text {dijon, francia, } 16 / 17}=0,97$ és a Metz $\bar{y}_{\text {metz,francia, } 1617}=1,13$ pontot gyüjtött mérkőzésenként. Ezek alapján a bennmaradáshoz viszonyított átlagos távolság $D L R T_{\text {francia, 16/17 }}=0,04$. Ugyanezen logika szerint a spanyol bajnokság újoncai átlagosan $D L R T_{\text {spanyol, 16/17 }}=0,06$ pontnyi távolságra voltak a bennmaradástól, igazolva ezzel a korábban megfogalmazott intuitív feltevést, miszerint a spanyol feljutó csapatok jobban teljesítettek ebben a szezonban.

Néhány első osztályban speciális rendszert hoztak létre a kiesést illetően. Általában van egy-két csapat, amely automatikusan kiesik az első osztályból, míg további egy csapat külön rájátszásra kényszerül egy másodosztályú csapat ellen, hogy kiharcolja a bennmaradást. Jelenleg például a német Bundesliga esetében a táblázat utolsó két helyén végzett együttes automatikusan kiesik a másodosztályba, míg a harmadik legrosszabbul teljesítő csapat egy rájátszásban küzd meg a másodosztály harmadik legjobb csapatával az első osztályú indulás jogáért. Amelyik csapat megnyeri az odavissza vágós párharcot, az indulhat a következő szezonban az élvonalban, a vesztes pedig a másodosztályban fog szerepelni. Az ilyen típusú első osztályú ligáknál azt feltételezzük, hogy amennyiben az első osztályú csapatnak sikerül felülkerekednie másodosztályú ellenfelén, és megnyeri a rájátszást, akkor az újonc csapatok teljesítményét is ezen csapat első osztályban elért teljesítményéhez mérjük. A Bundesliga 
2014/2015-ös szezonjában az újonc SC Paderborn 07 az utolsó, 18. helyen végzett 31 ponttal, míg a 16. helyen rájátszásra kényszerülő csapat a Hamburg SV lett 35 ponttal. Mivel a pótselejtezőn a Hamburg SV összesítésben 2:1-re nyert a Karlsruher SC ellen, az SC Paderborn 07 teljesítményét a Hamburg SV által elért pontszámhoz viszonyítjuk. Ekkor azt tesszük fel, hogy ha az SC Paderborn 07 csapata 4 ponttal többet szerzett volna, akkor a Hamburg SV csapatával egyenlő erősségü csapat lévén ők is megnyerték volna a rájátszást. Ha a rájátszást a másodosztályú csapat nyeri meg, akkor abban az esetben az újonc csapatok teljesítményét a rájátszást érő helyezés elötti csapat eredményéhez viszonyítjuk.

A (2)-(4) egyenlet által leírt mutatószámmal kapcsolatban fontos megjegyezni, hogy pontegyenlőség esetén a csapatok más teljesítményalapú mutatói döntik el a csapatok közötti rangsort. A 2008/2009-es szezonban a spanyol bajnokságban elöállt az az eset, hogy a 18. helyen végzett Real Betis ugyanannyi pontot szerzett, mint a 17. helyen álló Getafe, előbbi mégis kiesett a bajnokságból. Az általunk felvázolt módszertan azt feltételezi, hogy ebben az esetben a két csapat közötti különbség 0 , és a Real Betis tulajdonképpen elérte azt a teljesítményt, ami a bennmaradáshoz szükséges. A két csapat sorrendjéröl az döntött, hogy a Real Betis hazai pályán 2:2-re végzett a Getafe ellen, míg idegenben 0:0 lett az eredmény, összesítésben pedig az idegenben lőtt góllal a Getafe volt a jobb. Fontos megjegyezni, hogy bizonyos bajnokságokban nem az egymás elleni eredmény számít, hanem a gólkülönbség, tehát az egyes országokban különböző jellemzők számítanak pontazonosság esetén. Bár viszonylag ritkán fordulnak elő ilyen esetek, de ilyenkor nem egyértelmű az utolsó, még bennmaradást jelentő helyen végző csapat teljesítményének meghatározása.

A módszerrel kapcsolatban felmerülő probléma, hogy figyelmen kívül hagyja az első osztályban szereplő csapatok létszámában és a kieső csapatok számában rejlő különbségeket. Például az angol első osztályban 20 csapat versenyez egymással az utóbbi évtizedekben, azonban a német első osztályban csupán 18 csapat indulhat. Ennek ellenére előfordulhat, hogy mindkét ország élvonalában három-három csapat esik ki. Ekkor az angol első osztályban könnyebb kiharcolni a bennmaradást, hiszen a csapatok 15 százalékát szükséges megelözni a bennmaradás érdekében, ami a Bundesliga esetén már 17 százalék. A felvázolt problémák kezelésére a következőkben egy újabb méröszámot ismertetünk.

Az ÚJONCOK TÁVOLSÁGA A 20. PERCENTILISTŐL MÓDSZER • Az újonc csapatok teljesítményének összevetéséhez tehát szükségünk van egy olyan módszerre, amelyet nem befolyásol az adott első osztály létszáma, a kiesők száma, valamint az esetlegesen kiesésről döntő rájátszás eredménye. További fontos szempont, hogy a viszonyítási pont az első osztályú tagságot még éppen biztosító helyezéshez szükséges teljesítmény közelébe essen, hiszen vizsgálataink célja is az újonc csapatok bennmaradására vonatkozik. Tekintettel arra, hogy az alacsony létszámú, 10-14 csapatos ligákban többnyire egy-két kieső, míg a nagyobb létszámú, 16-20 csapatos ligákban két-három kieső van, jó viszonyítási alapot nyújt a pontszámok 20. percentilise (P20). Ahogy azt az 1. ábra is mutatja, az, hogy a vizsgált szezonokban az utolsó még éppen bennmaradó csapat pontszáma és a 20. percentilis értéke elég közel esnek egymáshoz, lehetővé teszi azt, 
hogy a 20. percentilis értékét egyfajta mesterséges bennmaradási küszöbként értelmezzük. Az így meghatározott viszonyítási pont további előnye, hogy különböző létszámú ligák esetében is jól összehasonlíthatóvá válnak az eredmények, és nem függnek a kiesés kapcsán felmerülő rájátszás eredményétől sem. Fontos megjegyezni, hogy a 20. percentilis közelsége az utolsó még éppen bennmaradó csapat pontszámához az európai labdarúgásra jellemzö. Más sportágakban esetleg eltérő módon határozhatják meg a kiesők számát, így másik kvantilis alkalmazása lehet kívánatos.

\section{1. ábra}

Az utolsó még éppen bennmaradó csapat pontszáma és a pontszámok 20. percentilise közötti kapcsolat



Forrás: saját szerkesztés a www.worldfootball.net weboldal adatai alapján.

Formailag az újoncok 20. percentilistől való távolsága (distance from 20th percentile, DP20) a következőképpen határozható meg. Jelölje a $p 20_{c, t}$ a $c$-edik ország $t$-edik szezonjában a csapatok által elért pontszámok 20. percentilisét. ${ }^{1}$ Ekkor a (4) egyenletet átalakítva megkapjuk a szóban forgó mutatószámot:

$d_{n, c, t}^{p 20}=\bar{y}_{n, c, t}-\frac{p 20_{c, t}}{m_{c, t}}$

és

${ }^{1}$ A 20. percentilis kiszámításához az $R$ programcsomag quantile függvényének alapértelmezett (7. típusú) beállítását használtuk. A módszerről bővebben Hyndman-Fan [1996] ad leírást. 
$D P 20_{c, t}=\frac{\sum_{n=1}^{N} d_{n, c, t}^{p 20}}{N_{c, t}}=\frac{\sum_{n-1}^{N} \bar{y}_{n, c, t}}{N_{c, t}}-\frac{p 20_{c, t}}{m_{c, t}}$.

Az 1. táblázatban bemutatott spanyol és francia példát folytatva, előbbi esetében a pontszámok 20. percentilise 35,8, utóbbiéban 37 pont volt. Ezeket az értékeket behelyettesítve az (5) és a (6) egyenletbe, azt kapjuk, hogy a La Ligában $D P 20_{\text {spanyol, } 16 / 17}=0,0404$, míg a Ligue 1 -ben $D P 20_{\text {francia, } 16 / 17}=0,0351$ ponttal voltak jobbak átlagosan az újonc csapatok mérkőzésenként a 20. percentilishez viszonyítva. A számítások ebben az esetben is a feljutó spanyol csapatok jobb teljesítményét támasztják alá, és ezáltal a spanyol másodosztályból feljutó csapatok is nagyobb nyomást fejtettek ki a korábban is első osztályú csapatokra.

A következőkben a három mutatószám alapján ismertetjük a vizsgált 21 európai labdarúgó-bajnokság élvonalaiban szereplő újonc csapatok teljesítményét, valamint a magyar és az angol első osztályú csapatok pénzügyi helyzetének elemzésén keresztül egy lehetséges magyarázattal szolgálunk az országok közötti különbségekre.

\section{Eredmények}

Az általunk elvégzett számításokat három külön részben mutatjuk be. Elsőként a 2007/2008 és a 2016/2017 közötti szezonok alapján vizsgáljuk meg a feljutó csapatok teljesítményét az általunk bemutatott három mutató kiszámításával. Majd feltárjuk az újonc csapatok élvonalbeli bennmaradással kapcsolatos tendenciáit. Végül bemutatjuk a magyar és az angol bajnokságban a feljutás és a kiesés pénzügyi vonzatát.

\section{Az európai labdarúgó-bajnokságok újonc csapatainak teljesítménye}

Ahogy azt már korábban az alkalmazott módszertani rész elején is említettük, a feljutó csapatok teljesítményét használjuk a korábbi első osztályú csapatokra nehezedő nyomás mérésére. Ez úgy tehető meg a legegyszerübb módon, hogy megvizsgáljuk, milyen arányban sikerült az újoncoknak bennmaradniuk az élvonalban. Tekintettel arra, hogy viszonylag alacsony számú újonc csapat szerepel a különféle ligákban, egy-egy újonc csapat kiemelkedő teljesítménye torz kép kialakulásához vezethet, emiatt egy tízéves periódust választottunk ki az eredmények megfelelö értékelésére. Az erre vonatkozó eredményeket az (1) egyenlet felhasználásával számítottuk ki, majd a 2007/2008-2016/2017 közötti szezonokra kapott értékek átlagát tüntettük fel a 3. táblázatban. Az újonc csapatok bennmaradási aránya $(R R R)$ mellett a táblázatban látható az újonc csapatok számának átlaga $(\bar{N})$ és a bennmaradó újonc csapatok átlaga $(\bar{R})$ is. A számokból látható, hogy néhány országban, mint például Angliában, Spanyolországban és Görögországban, nem változott a feljutó csapatok létszáma, azonban a legtöbb élvonalbeli ligáról ez nem mondható el. A bennmaradási arány mutató előnye, hogy egyszerüen meghatározható, és képes kezelni a feljutók számának változékonyságát. 


\section{3. táblázat}

Az újonc csapatok bennmaradási aránya $(R R R)$ az európai labdarúgó-bajnokságok élvonalában a 2007/2008-2016/2017 közötti szezonok átlaga alapján

\begin{tabular}{|c|c|c|c|c|c|c|c|}
\hline Ország & $\bar{R}$ & $\bar{N}$ & $R R R$ & Ország & $\bar{R}$ & $\bar{N}$ & $R R R$ \\
\hline Ausztria & 1,1 & 1,1 & 1 & Olaszország & 2,0 & 3,0 & 0,67 \\
\hline Svájc & 1,1 & 1,2 & 0,92 & Svédország & 1,6 & 2,4 & 0,67 \\
\hline Szerbia & 2,4 & 2,7 & 0,89 & Hollandia & 1,4 & 2,1 & 0,67 \\
\hline Belgium & 1,4 & 1,7 & 0,82 & Magyarország & 1,3 & 2 & 0,65 \\
\hline Norvégia & 1,9 & 2,5 & 0,76 & Görögország & 1,9 & 3 & 0,63 \\
\hline Skócia & 0,9 & 1,2 & 0,75 & Anglia & 1,8 & 3 & 0,6 \\
\hline Spanyolország & 2,2 & 3,0 & 0,73 & Csehország & 1,2 & 2 & 0,6 \\
\hline Dánia & 1,5 & 2,1 & 0,71 & Franciaország & 1,7 & 3 & 0,57 \\
\hline Horvátország & 1 & 1,4 & 0,71 & Oroszország & 1,3 & 2,5 & 0,52 \\
\hline Portugália & 1,5 & 2,1 & 0,71 & Románia & 1,8 & 3,5 & 0,51 \\
\hline Németország & 1,6 & 2,4 & 0,67 & & & & \\
\hline
\end{tabular}

Forrás: saját szerkesztés a www.worldfootball.net weboldal adatai alapján.

A feljutó csapatok bennmaradási arányát vizsgálva az országok között jelentős különbségek figyelhetők meg. Ausztriában az újonc csapatoknak 100 százalékban sikerült kiharcolniuk a bennmaradást a feljutást követő szezonban, míg a román és az orosz élvonalat tekintve ez az érték épphogy meghaladja az 50 százalékot. A top 5 európai első osztályú liga újoncai közül a francia csapatok 57 , az angolok 60 , az olaszok és a németek 67, a spanyolok pedig 73 százalékban kerülték el a kiesést. Magyarország esetében a 20 feljutó csapatból 13 tudta biztosítani első osztályú tagságát a vizsgált időszakban.

A bennmaradási arányt összevetve a feljutó csapatok számával, az látható, hogy azokon a bajnokságokon, ahol átlagosan kettőnél kisebb a feljutók száma, nagyobb arányban maradnak bent az újonc csapatok az első osztályban. Ezek közé az országok közé tartozik Ausztria, Belgium, Horvátország, Skócia és Svájc is. Ez is jelzi a módszer azon hiányosságát, hogy nem veszi figyelembe, hogy kisebb számú feljutó esetében a kiesők száma is kevesebb, így az újoncoknak könnyebb bennmaradni.

$\mathrm{Az}$ újonc csapatok bennmaradási arányát mérő módszer másik hiányossága, hogy nem veszi figyelembe a feljutó csapatok távolságát a kiesés elkerülésétől, és ugyanolyan értékünek tekinti azt a csapatot, amelyik éppenhogy csak megörizte élvonalbeli tagságát, mint amelyik a kiesést messze elkerülve, a középmezőnyben vagy akár az élmezőnyben végzett. Ennek fényében a (2)-(4) egyenletek felhasználásával megnéztük a vizsgált 21 európai ország első osztályában szereplő újonc csapatok bennmaradástól vett átlagos távolságát (DLRT) is. A 2. ábrán hasonlóan a 3. táblázathoz - ebben az esetben is a 2007/2008-2016/2017 közötti szezonok átlagértékeit tüntettük fel.

A fekete pont az utolsó még bennmaradó csapat meccsenkénti pontszámát jelöli az említett tíz szezon átlagára vonatkozón, míg a szürke pont a vizsgált időszak újonc 


\section{2. ábra}

Az élvonalbeli újonc csapatok távolsága a bennmaradástól a $D L R T$ mutató alapján, 2007/2008-2016/2017

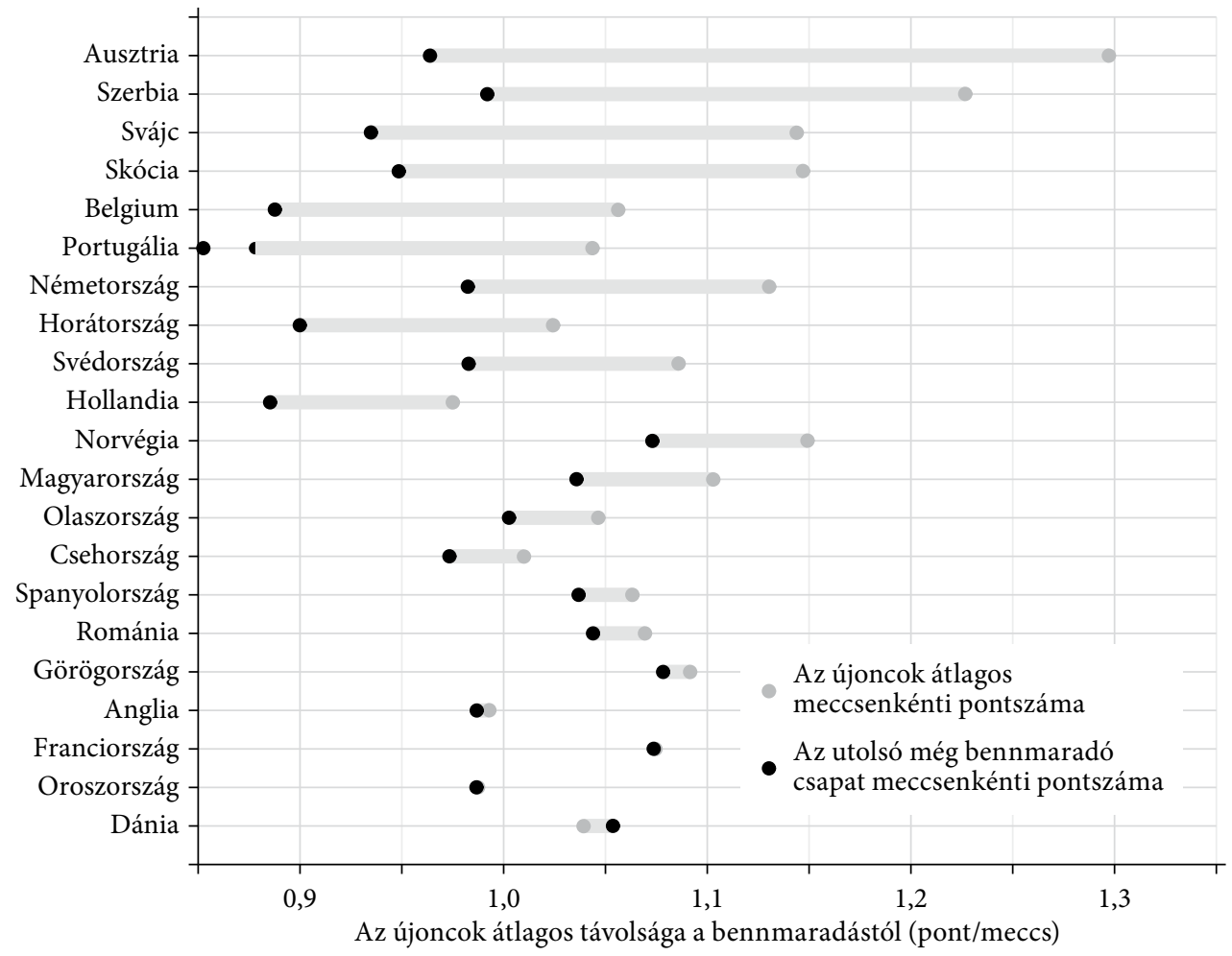

Forrás: saját szerkesztés a www.worldfootball.net weboldal adatai alapján.

csapatainak átlagos mérkőzésenkénti pontszámát mutatja. A két pontot összekötő szürke egyenes a bennmaradástól vett átlagos távolságot (DLRT) ábrázolja, az országokat pedig a távolságok mérete alapján rangsoroltuk. Az eredmények azt mutatják, hogy az $R R R$ mutatóhoz hasonlóan az osztrák első osztály újoncai teljesítettek a legjobban, mérkőzésenként átlagosan 0,33 ponttal szereztek többet, mint ami átlagosan a kiesés elkerüléséhez szükséges. Szintén jól teljesítettek a szerb, a svájci és a skót élvonal feljutó csapatai is, amelyek átlagosan 0,23, 0,21 és 0,20 ponttal értek el többet a viszonyítási ponthoz képest. Ezzel szemben Görögországban, Angliában, Franciaországban és Oroszországban az újonc csapatok átlagosan közel azonos meccsenkénti pontot értek el a még átlagosan éppen nem kiesést jelentő teljesítményhez képest, míg Dániában az újoncok mérkőzésenként 0,01 ponttal kevesebbet is gyüjtöttek. A magyar Nemzeti Bajnokság ebben a tekintetben szintén a rangsor közepén szerepelt.

Érdemes külön megvizsgálni a top 5 európai első osztályú liga újoncainak teljesítményét is. A bennmaradási arányt tekintve nem tapasztalható jelentős különbség közöttük, azonban a 2. ábrát tanulmányozva szembetünik a német Bundesliga újoncainak kiugró teljesítménye. A német élvonal feljutó csapatai mérkőzésenként átlagosan 0,15 ponttal értek el többet az utolsó még bennmaradó helyen végző csapathoz 
képest a tíz szezon átlagában. Ezzel szemben az olasz újoncok csak 0,04, a spanyolok 0,03 , az angolok pedig 0,01 ponttal szereztek többet. Németország elönye alapvetően két tényezőből fakad: a német élvonalban a másik négy bajnoksághoz képest kevesebb meccsenkénti pont szükséges a kiesés elkerüléséhez, valamint az újonc csapatok mérkőzésenkénti pontszáma is magasabb a többi liga esetében. Angliában és Franciaországban különösen alacsony a DLRT mutató értéke, de míg előbbi esetében ez az újonc csapatok alacsony pontszámával magyarázható, addig Franciaországban inkább a magas bennmaradási küszöbnek tudható be.

A 2. ábrára nézve szintén az látható, hogy a rangsor elején áll Ausztria, Svájc, Skócia és Horvátország, ahol az élvonalban szereplő csapatok létszáma és ebből fakadóan a kieső-feljutó csapatok száma is alacsony. Az eredményeket árnyalja, hogy a rangsor második helyén szereplő Szerbiában 16 csapat szerepel az élvonalban, továbbá a rangsor legvégén található dán első osztályt csupán 12 csapat alkotja. Utóbbi különösen érdekes, hiszen a bennmaradási arányt tekintve Dánia értéke viszonylag magas, azonban a pontszámok alapján az látható, hogy a dán újonc csapatok kevésbé kerülik el a kiesést. Ezt a némileg ellentmondó helyzetet az oldja fel, hogy a feljutó dán csapatok ugyan viszonylag sokszor kerülik el a kiesést, viszont amikor ez megtörténik, akkor nagyon kevés pontot gyüjtenek. A 2014/2015-ös szezon erre a jelenségre nyújt kitűnő példát, amikor az újonc Silkeborg IF csupán 14 pontot gyüjtött 33 mérkőzésen, 23 ponttal lemaradva a 10. helyen végző, már bennmaradást jelentő csapattól.

Ahogy azt a módszertani részben részletesen kifejtettük, az utolsó még bennmaradást érö helyet elérő csapathoz való viszonyítás több szempontból is problémákat vet fel. A problémák kezelésére meghatároztunk egy újabb, harmadik mutatószámot, amely az újonc csapatok mesterséges bennmaradási küszöbhöz viszonyított teljesítményét méri. Ez látható a 3. ábrán, ahol szintén tíz szezon átlagos értékeit tüntettük fel. A 2. ábrához képest annyi a változás, hogy ebben az esetben a fekete pont a mecscsenkénti pontszámok 20. percentilisét mutatja. Ennek megfelelően a két pont közötti távolság mérete a DP20 mutató értékének felel meg.

A 3. ábrát tanulmányozva, jól látható, hogy a fekete pontok az $x$ tengelyen nagyobb értéket vesznek fel a 2. ábrához képest, azaz a mérkőzésenkénti pontszámok 20. percentilisét (fekete pontok a 3. ábrán) alkalmazva a viszonyítási pont - Románia kivételével - minden esetben enyhén jobbra tolódott. A 20. percentilis helyzete alapvetően az első osztályon belüli versenyegyensúlytól függ. Ha az első osztály koncentráltabb, a pontok nagy részét néhány csapat szerzi meg, akkor a 20. percentilis értéke alacsonyabb lesz. Egy kiegyenlített bajnokságban a 20. percentilis értéke magasabb lesz. Ez biztosítja, hogy minden esetben az első osztály hátsó (alsó 20 százalék) csapataihoz viszonyítsuk az újoncok teljesítményét. A 20. percentilis értéke alapján a norvég, a francia és a görög első osztály volt a legkiegyenlítettebb a vizsgált időszakban, míg a belga és portugál első osztályban nagy volt az alsó 20 százalék lemaradása.

Érdekes eredmény, hogy az országok rangsora részben nagyon hasonlít a $D L R T$ mutató alapján létrejött rangsorhoz. Ugyanúgy Ausztria, Szerbia, Svájc és Skócia állt a rangsor tetején, valamint Anglia, Franciaország és Dánia a rangsor alján foglalt helyet. Másrészt viszont az is észrevehetö, hogy néhány országban jelentősen megváltozott az újonc csapatok teljesítménye a kiesést illetően. A még éppen a kiesést elkerülö helyezéshez való 
3. ábra

Az élvonalbeli újonc csapatok távolsága a bennmaradástól a DP20 mutató alapján, 2007/2008-2016/2017

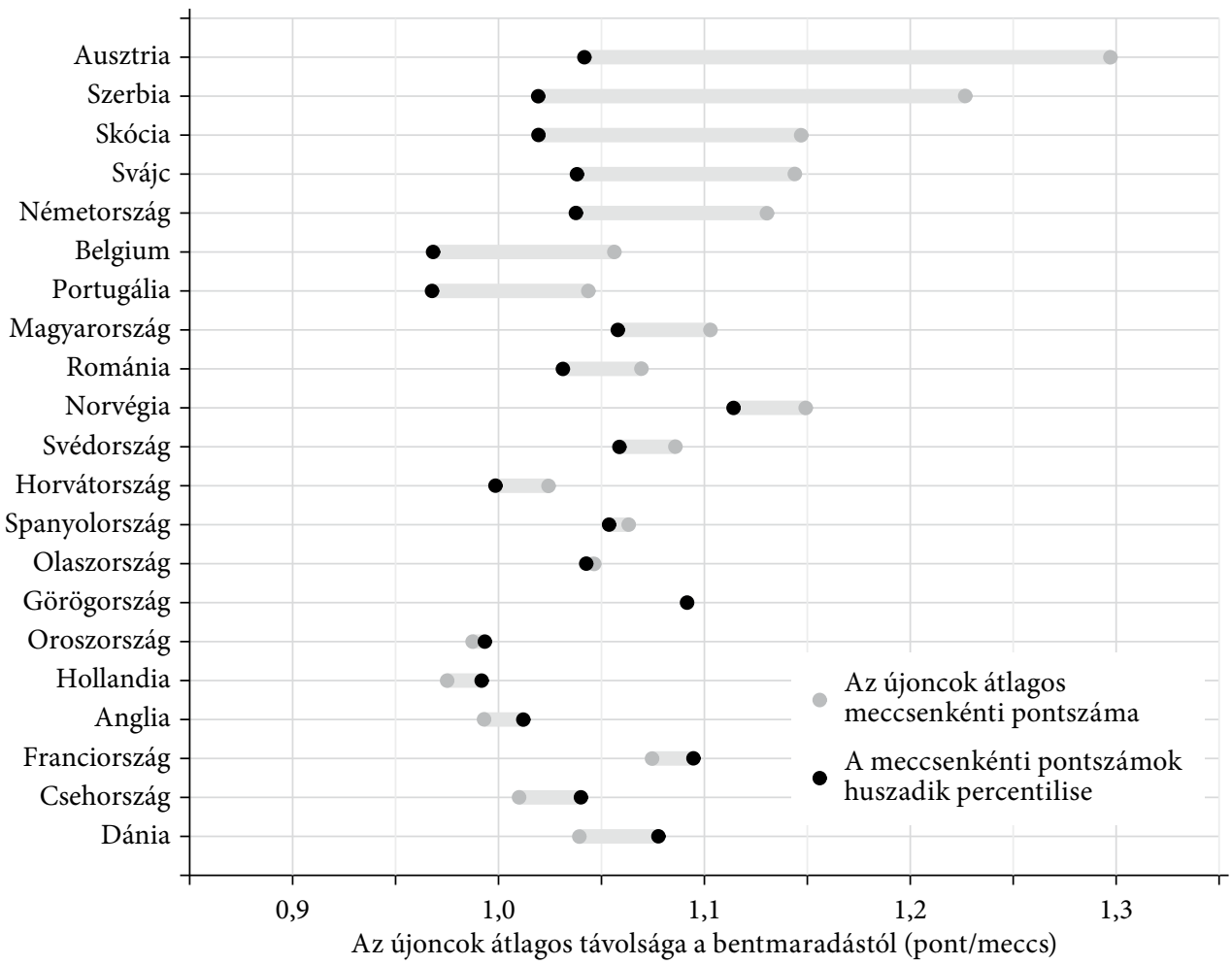

Forrás: saját szerkesztés a www.worldfootball.net weboldal adatai alapján.

viszonyítás szerint Románia a 15. volt a rangsorban, míg a 20. percentilishez való viszonyításnál már a 9. helyen szerepelt. Németország szintén javított helyezésén, azonban Csehország és Horvátország esetében visszaesést lehetett tapasztalni. A top 5 bajnokságot összehasonlítva még szembetünőbb, hogy a német Bundesligában szerepeltek a legjobban a feljutó csapatok, szemben az olasz, az angol és a francia újoncokkal, ahol a feljutó csapatok a 20. percentilis által jelzett bennmaradási küszöböt sem érték el.

A DLRT és DP20 mutató közti eltérés akkor nagy, ha a valós bennmaradást jelentö küszöb messze esik a 20. percentilistől. Másképp szemlélve, a DLRT mutató torzítása ilyenkor jelentős. Horvátország és Csehország esetében például a DLRT mutató felfelé torzít, ami abból következik, hogy a vizsgált időszakban a 20. percentilishez viszonyítva túl kevés kieső volt, így a bennmaradási küszöb a várhatónál lejjebb került, megkönnyítve ezzel a bennmaradást.

Az egyes mutatók értékeléséhez kiszámítottuk, hogy milyen mértékben korrelálnak egymással, illetve az adott évben az első osztályban részt vevő csapatok, az újoncok és a kiesők számával (4. táblázat). Az RRR és a DLRT mutató kapcsán kritikaként megjegyeztük, hogy a bennmaradáshoz szükséges pontszám függ a kieső csapatok számától. Erre utal a szignifikáns negatív korreláció $(-0,29)$ is a kiesők számával. A DP20 mutató 
azonban orvosolni tudja ezt a problémát, mivel sem a kiesők, sem a feljutók, sem az első osztályban részt vevő csapatok számával nem korrelál szignifikánsan. A korrelálatlanság önmagában nem bizonyítja, azonban utal rá, hogy a DP20 valóban független a bajnokság lebonyolítási rendszerétől. Az egyes mutatók egymással erősen pozitívan korrelálnak, a $D P 20$ és a $D L R T$ mutató között nagyon magas együtthatót $(0,92)$ kapunk. Ebből az látszik, hogy hasonlóan a DLRT mutatóhoz, a DP20 is alapvetően az újoncok bennmaradási küszöbhöz viszonyított teljesítményét méri, azonban kevesebb hibával. Tehát a DP20 változó alkalmazását javasoljuk az újonc csapatok teljesítményének legpontosabb értékelésére és az első osztály előnyének mérésére.

\section{4. táblázat}

Pearson-féle korrelációs együtthatók az újoncok teljesítményét mérő mutatók és a bajnokság különböző változói között

\begin{tabular}{llllccc}
\hline & $R R R$ & $D L R T$ & $D P 20$ & $\begin{array}{c}\text { Első osztályú } \\
\text { csapatok száma }\end{array}$ & $\begin{array}{c}\text { Feljutók } \\
\text { száma }\end{array}$ & $\begin{array}{c}\text { Kiesők } \\
\text { száma }\end{array}$ \\
\hline$R R R$ & $1,00^{*}$ & $0,69^{*}$ & $0,64^{*}$ & $-0,02$ & $-0,13^{*}$ & $-0,29^{*}$ \\
$D L R T$ & $0,69^{*}$ & $1,00^{*}$ & $0,92^{*}$ & $-0,03$ & $-0,17^{*}$ & $-0,29^{*}$ \\
$D P 20$ & $0,64^{*}$ & $0,92^{*}$ & $1,00^{*}$ & $-0,02$ & $-0,06$ & $-0,04$ \\
\hline
\end{tabular}

Megjegyzés: az együtthatókat a 2. táblázatban bemutatott teljes adatállomány felhasználásával számítottuk ki.

${ }^{*} p<0,05$.

Forrás: saját szerkesztés a www.worldfootball.net weboldal adatai alapján.

A három különböző mutató alapján bemutattuk a 2007/2008-2016/2017 közötti szezonokban az újonc csapatok teljesítményét. A következőkben a feljutó csapatok teljesítményének időbeli alakulását vizsgáljuk meg, azonban ezt kizárólag a DP20 mutató szerint fogjuk megtenni.

\section{Az újonc csapatok bennmaradással kapcsolatos időbeli tendenciái}

Ha az első osztályú újonc csapatok teljesítményét szezononként tüntetnénk fel egy ábrán, eléggé ingadozó görbéket kapnánk. Ennek kezelésére tízéves mozgóátlagokat számolunk, majd ezek alapján ábrázoljuk a feljutó csapatok eredményeit. Ebben az esetben a 2016/2017-es szezonhoz tartozó értéket a 2007/2008-2016/2017 közötti szezonok átlaga szerint határozzuk meg, ahogy azt a korábbiakban is tettük, míg a 2015/2016-os szezon értéke a 2006/2007-2015/2016 közötti szezonok értékeinek átlaga szerint adódik, és így tovább.

A 4. ábra a top 5 európai bajnokság első osztályú újonc csapatainak teljesítményét mutatja a DP20 mutató alapján. Jól látható, hogy a kezdeti években az angol élvonal feljutó csapatai érték el a legjobb eredményeket a többi első osztályú liga újoncaihoz képest, meccsenként több mint 0,2 ponttal gyüjtöttek többet a pontszámok 20. percentiliséhez viszonyítva. Az évek elteltével azonban az angol újonc csapatok 
eredményessége csökkent, és eltekintve az 1970-es évek végétől a 1980-as évek végéig tartó időszaktól, folyamatos csökkenés tapasztalható. A francia első osztály feljutóinak eredményességében az 1980-as évek közepéig csökkenés, majd ezután egy évtizedes javulás figyelhető meg, végül az 1990-es évek közepétől ismét negatív trend látható. Olaszország esetében kisebb-nagyobb kilengések szerint a kezdeti időponttól egészen az ezredfordulóig csökkent a feljutók teljesítménye.

\section{4. ábra}

Az újonc csapatok teljesítményének időbeli alakulása a legnépszerübb európai első osztályú ligákban a DP20 mutató alapján, 10 éves mozgóátlagok, 1966/1967-2016/2017

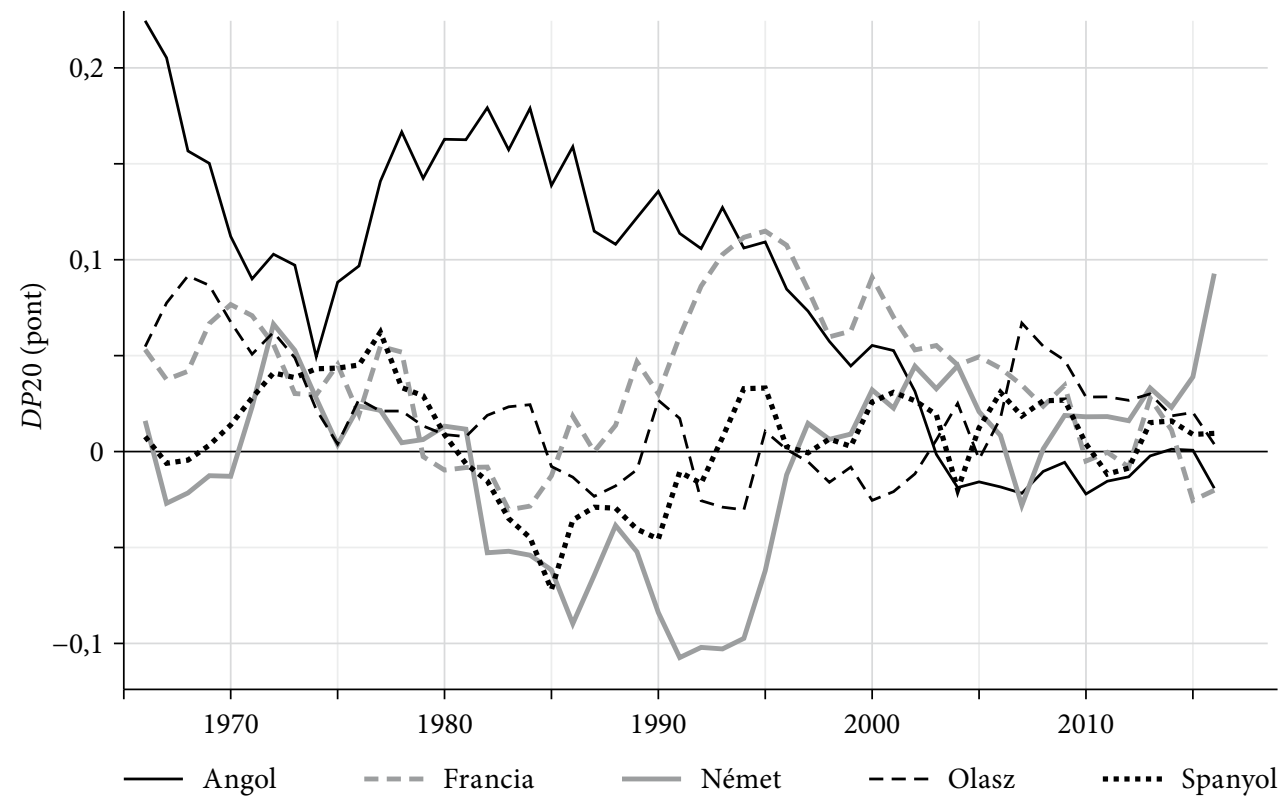

Forrás: saját szerkesztés a www.worldfootball.net weboldal adatai alapján.

Az ezredforduló után 2008-ig emelkedés következett be, amely után pedig stabilizálódott a DP20 mutató értéke. Végezetül a német első osztály újoncainál is csökkenő tendencia látható az időszak elején. Az ország újraegyesítését és az első osztály létszámának átmeneti emelését követően a német feljutó csapatok teljesítménye egyre jobbá vált. A pozitív trend a 2000-es években megtört, azonban számos kiemelkedő újonc eredményének - például a TSG Hoffenheim feljutást követő előkelő helyezése köszönhetően ismét növekedett az újoncok teljesítménye. Ehhez feltételezhetően az is hozzájárulhatott, hogy változtattak a feljutás és a kiesés szabályain. A 2008/2009es szezon elött a 18 csapatos ligában a 16. helyen végző csapat automatikusan kiesett a másodosztályba, viszont ettől a szezontól kezdődően a másodosztály 3 . helyén végző csapatával egy rájátszásban még kiharcolhatta a bennmaradást.

A többi vizsgált 15 európai bajnokság élvonalában szereplö újonc csapatok időbeli teljesítménye a Függelék F1-F3. ábráin látható. A magyar első osztállyal kapcsolatban érdemes megemlíteni, hogy a kezdeti időpontot követően egy ugrás látható 
az 1995/1996-os szezonra, ami többek között az akkor újonc MTK 5. helyezésének köszönhető. Ezt követően azonban kisebb-nagyobb kilengések szerint a feljutó csapatok teljesítményének enyhén csökkenő tendenciája rajzolódik ki.

\section{Esettanulmány - a magyar és az angol feljutó és kieső csapatok pénzügyi helyzetének elemzése}

A szakirodalom áttekintésénél is említettük, hogy korábbi elemzések az angol első és másodosztályú csapatok pénzügyi helyzete között jelentős különbségeket mutattak ki (Goddard [2014], Noll [2002]). A csapatok döntéseit részben gazdasági célok motiválják, és az első osztályban való szereplés pénzügyi előnyökkel jár, például a nagyobb pénzdíjazáson, a magasabb közvetítési díjakon és a több nézőn keresztül. Ezek alapján azt feltételezzük, hogy azokban a bajnokságokban, ahol az első osztályú csapatok pénzügyi előnye nagyobb, ott a másodosztályból feljutó csapatok teljesítménye alacsonyabb a bennmaradást tekintve. A következökben a magyar és az angol bajnokság példáján keresztül mutatjuk be, hogy az első osztály pénzügyi előnye milyen hatást gyakorol az újonc csapatokra. Az elemzés alapjául szolgáló adatokat a srekk.pte.hu weboldalon található sportgazdasági adatbázis és Goddard [2014] tanulmánya szolgáltatja.

Az angol bajnokságban a méréseink alapján az 1980-as évektől kezdődően egyre csökkent az újonc csapatok teljesítménye, így napjainkra már a legnépszerübb öt bajnokság közül itt figyelhető meg az első osztály legnagyobb előnye, ahogy azt a 4. ábra is megmutatja. Ezzel szemben Magyarországon az újoncok teljesítménye az utolsó tíz szezonban a bajnokságok többségénél magasabb, ami a 3. ábrán lévő rangsorból is látható. A 2016/2017-es szezontól kezdődő időszakban a feljutók közül a Puskás Akadémia, a Mezőkövesd és a Kisvárda csapata is jó teljesítménnyel tudott bennmaradni az élvonalban, és a tanulmány írásáig meg is őrizték első osztályú tagságukat. Ehhez hozzájárult, hogy a feljutás kiharcolását követő szezonban mindhárom csapat jelentős ráfordításokat eszközölt a bennmaradás érdekében, átlagosan nagyjából megduplázták a személyi jellegü ráfordításaikat. Ugyanakkor Angliában 2013 és 2018 között több újonc csapat egy élvonalban töltött szezon után kiesett a másodosztályba (Cardiff City, QPR, Burnley, Norwich City, Middlesbrough, Hull City, Fulham). Ami még érdekesebb, hogy ezek közül a Middlesbrough és a QPR kivételével mindegyik csapat kétszer is feljutott az első osztályba az elmúlt évtizedben, ám ott nem tudták hosszú távon biztosítani tagságukat. Ez a jelenség arra utal, hogy Angliában az újonc csapatok nagy része ma sem képes a feljutást követően leküzdeni a pénzügyi hátrányát és hoszszú távon is versenyképes csapatot összerakni, ami egybecseng Noll [2002] és Goddard [2014] korábbi időszakokra vonatkozó megállapításaival.

Az 5. ábra tanulsága szerint Angliában az 1998-2007 és a 2012-2017 közötti időszakokat összehasonlítva növekedett az első és a másodosztály közötti szakadék a bevételeket tekintve. A 2012-2017-es időszakban a feljutó csapatok bevétele átlagosan több mint négyszeresére emelkedett, míg a kiesőké 44 százalékkal csökkent az elöző szezonhoz képest. Az ezredforduló óta az újoncok teljesítményét mérő $D P 20$ tízéves mozgóátlaga is 
csökkenő tendenciát mutat, ami arra utal, hogy az osztályok közötti pénzügyi különbségek hozzájárulhatnak a másodosztályból feljutó csapatok rosszabb élvonalbeli teljesítményéhez. Ehhez képest Magyarországon viszont a bevétel növekedése jóval alacsonyabb a feljutást követően, miközben a DP20 mutató értéke magasabb. Ez arra utal, hogy Magyarországon az újoncoknak Angliához képest jóval kisebb pénzügyi hátrányt kell ledolgozniuk, így jobb teljesítményre képesek a feljutást követően. További fontos különbség, hogy Magyarországon a kieső csapatok bevétele a kiesés ellenére is növekszik, és nem figyelhető meg az angol kieső csapatoknál jellemző csökkenés.

5. ábra

A feljutás és a kiesés pénzügyi következményei az angol és a magyar bajnokságban
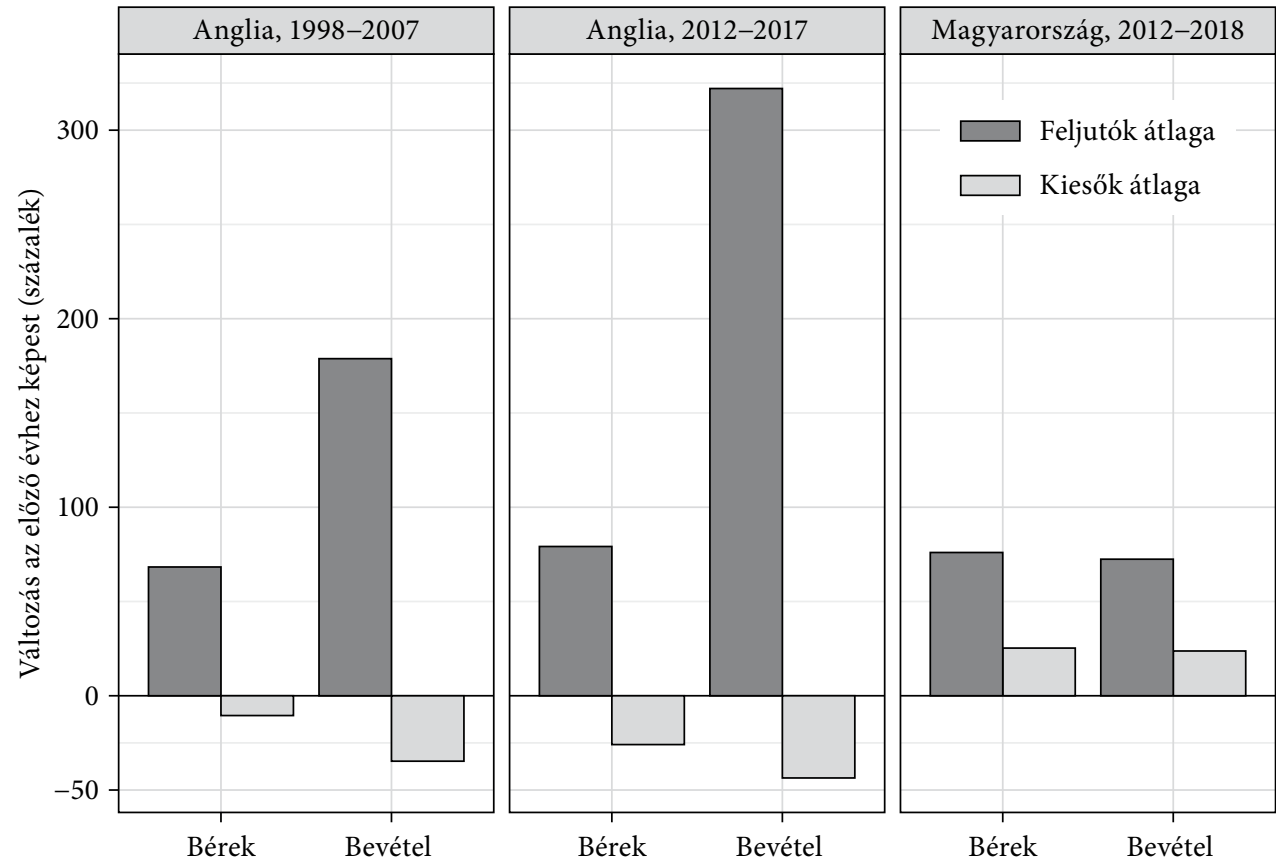

Megjegyzés: a bérek változásának számítása a személyi jellegủ ráfordítások alapján történt, így nem kizárólag a játékosok fizetését tartalmazza. Hiányzó adatok a feljutók közül: Egri FC (2012/2013), Dunaújváros (2014/2015), Puskás Akadémia (2013/2014), Brighton (2017/2018), Bradford (1998/1999), Leicester (2002/2003). Hiányzó adatok a kiesők közül: Győri ETO (2017/2018), Dunaújváros (2015/2016) és a magyar Nemzeti Bajnokság 2014/2015-ös szezonja után a harmad- vagy alsóbb osztályba sorolt csapatok.

Forrás: saját szerkesztés a www.srekk.pte.hu weboldalon található sportgazdasági adatbázis és Goddard [2014] adatai alapján.

A csapatok bevételei mellett szintén fontos figyelembe venni, hogyan változnak a csapatok személyi jellegü ráfordításai, amelyek nemcsak a játékosokra terjednek ki, hanem az edzői és a szakmai stábot is magukban foglalják. Az 5. ábráról az olvasható le, hogy a magyar feljutó csapatok átlagos személyi jellegü ráfordításai a bevételekkel közel azonos arányban növekedtek, míg az angol újoncoknál a bérek növekedése 
meg sem közelítette a bevételnövekedést. Ez azt jelenti, hogy a magyar újonc klubok a bevételük növekedéséhez képest jelentős személyi beruházásokat hajtanak végre a bennmaradás érdekében, ami jobb képességü játékosok szerződtetésében, az edzői stáb fejlesztésében és a meglévő játékosok béremelésében is megnyilvánulhat. Ezzel szemben az angol újoncok a bevételnövekedésükhöz képest jelentősen kisebb arányban növelik a személyi jellegü ráfordításaikat, és a bevételek jelentős részét profitként könyvelik el. Tehát a bérek alapján az látszik, hogy egy átlagos angol újonc csapat a magyarokhoz viszonyítva kisebb erőfeszítést tesz a bennmaradás érdekében, ami szintén magyarázatot adhat a feljutó csapatok teljesítményében található eltérésekre a magyar és az angol bajnokság között.

Noll [2002] rávilágít arra, hogy az angol feljutó csapatok alacsony ráfordításának fontos oka, hogy a feljutás még egy gyors újbóli kiesés után is permanens hasznokkal jár együtt. Egyrészt Angliában a kiesők három éven keresztül juttatásokat kapnak az angol élvonal közvetítői díjaiból, másrészt az egyszeri feljutás hosszabb távon növeli meg a szurkolói érdeklődést és ezáltal a nézőszámot.

Az 5. ábra segítségével bemutatott pénzügyi elemzés egy másik lehetséges magyarázatra mutat rá. Mivel a két osztályban elérhető bevételek között jelentős eltérések jelentkeznek, a kiesés pénzügyi következménye még az említett közvetítői díjakból származó, kompenzáló juttatások ellenére is jelentős. A csapatok általában egy évnél hosszabb időre kötnek szerződéseket a játékosok és a stábtagok fizetésével kapcsolatban. Ha egy klub a feljutást követően nagymértékü beruházásokat hajt végre és játékosvásárlásokba kezd a bennmaradás kiharcolása érdekében, akkor ez jelentős mértékü kockázattal jár együtt a hosszabb távra szóló szerződések miatt. Amennyiben a klub a beruházások ellenére végül mégis kiesik a másodosztályba, úgy alacsonyabb bevételek mellett szükséges kigazdálkodnia a korábban vállalt, nagyobb mértékű bérköltségeket, ami végső soron a klub veszteséges müködését idézheti elő. Így azoknak az újonc csapatoknak, amelyeknek várhatóan nincs elégséges piaca, amely mellett kigazdálkodhatók a magasabb bérek, a túlzott kockázat miatt nem éri meg a lehetséges bennmaradás érdekében jelentős költségeket vállalni. A magyar újonc csapatoknál a feljutás utáni költekezés kockázata alacsonyabb, mert a két osztály között kisebb a bevételekben megfigyelt különbség, esetleges kiesés esetén sem kell jelentős bevételcsökkenéstöl tartaniuk.

Összességében arra következtethetünk, hogy egyrészt az első osztály pénzügyi fölénye, másrészt a feljutók és a kiesők motivációi nagyban meghatározzák az újonc csapatok versenyképességét az első osztályban.

\section{Összefoglalás}

Tanulmányunkban 21 európai labdarúgó-bajnokság első osztályú újonc csapatainak bennmaradással kapcsolatos teljesítményét vizsgáltuk meg. Három új mérőszámot is bemutattunk, amelyek közül a pontszámok 20. percentilisén alapuló módszer (DP20 mutató) tulajdonságai a legkedvezőbbek, mert egyrészt figyelembe veszi a pontkülönbségeket, másrészt független a liga feljutásos/kieséses rendszerétől. Az eredmények 
alapján azt találtuk, hogy az országok között jelentős különbségek figyelhetők meg abban a tekintetben, hogy a másodosztályból feljutó csapatok milyen nyomást képesek helyezni a korábban is az első osztályban szereplő csapatokra. A dinamikus vizsgálatok feltárták, hogy a feljutó csapatok teljesítménye időben jelentősen változott, és az egyes országok tekintetében is más tendenciák érvényesülnek a különböző idöszakokban. Végül, a magyar és az angol első és másodosztályú csapatok pénzügyi helyzetének elemzésével feltártunk egy lehetséges magyarázatot az országok között megfigyelt különbségekre vonatkozóan.

Korábbi kutatások alapján, ha egy bajnokság csapatainak az eredményessége változékonyabb, az kedvező hatással van a nézőszámokra (Gyimesi [2020], Humphreys [2002], Krautmann-Hadley [2006]). Ezek a kutatások csak a bajnokságon belüli változásokat elemzik, azonban ha a bajnokságon belüli variabilitás hatással van a keresletre, akkor feltételezhetö, hogy a bajnokságok közötti mozgásnak is van szerepe a kereslet alakulásában. Ennek empirikus vizsgálata további kutatásra vár, azonban jelen tanulmány közelebb visz a hierarchikus európai labdarúgó-bajnokságok közötti mobilitás megértéséhez. Eredményeink kizárólag a feljutást követő szezonra terjednek ki, azonban érdekes kérdés lehet az is, hogy az újoncok hosszabb távon milyen teljesítményre képesek. A Leicester Citynek a feljutást követő második évben 10 pontos fölénnyel sikerült megnyernie az angol Premier League 2015/2016-os kiírását, ami nem jelenik meg a bemutatott mutatószámokban, mégis egy olyan váratlan teljesítmény, ami érdekesebbé teheti a bajnokságot. A hosszabb távú dinamika vizsgálata szintén további kutatási irány lehet.

Azt találtuk, hogy Angliában, Franciaországban, Csehországban és Dániában különösen rosszul teljesítenek a feljutó csapatok az első osztály 20. percentiliséhez képest. Ez az eredmény a jövőre nézve kedvezötlen következményekkel járhat ezekben a bajnokságokban, mivel egy pozitív visszacsatolási folyamat eredményeként egyre jobban leszakadhat a másodosztály, és az élvonalbeli csapatok helye bebetonozódhat. Ezzel szemben például az osztrák, a szerb és a top 5 liga közül a német feljutók nagyobb mértékben fel tudják venni a versenyt a korábban is az első osztályban szereplő csapatokkal, ami javítja az első osztály változékonyságát. Azt is megmutattuk, hogy a trendek időben változnak, egykoron az angol első osztály előnye volt a legkisebb a top 5 bajnokság közül, de ez mára az ellenkezőjére fordult.

Néhány ligában alacsony számú (10-12) csapat szerepelhet jelenleg az első osztályban, aminek fö motivációja, hogy alacsonyan tartsák a csapatok közötti különbségeket, és megmaradjon a versenyegyensúly az első osztályon belül. Ugyanakkor több ilyen bajnokságban a feljutó csapatok átlagosan bőven a bennmaradási küszöb felett teljesítenek - például Ausztriában, Svájcban és Skóciában -, ami arra utal, hogy több mint 10-12 versenyképes csapat müködik az adott országban. Tehát az első osztály esetleges bővítése után sem romlana jelentősen a versenyegyensúly. Ugyanakkor azokban a nagyobb létszámú (16-20 csapatos) bajnokságokban, ahol a feljutók átlagos mérkőzésenkénti pontszáma alacsony, és az első osztály 20. percentilise is messze elmarad a középmezőnytől - például Hollandiában, Angliában és Oroszországban -, indokolt lehet az első osztályú csapatok létszámának csökkentése a versenyegyensúly helyreállítása érdekében. 
Eredményeink alapján a belga és a portugál bajnokságban úgy volt magas a $D P 20$ mutató értéke (ekkor az első osztály előnye kicsi), hogy alacsonyabb volt mind a bennmaradási küszöb, mind a 20. percentilis értéke a többi ligához képest. Ez azt mutatja, hogy az első osztály kiegyenlítetlen, a kisebb csapatok nagy lemaradással küzdenek, azonban a másodosztály nincs nagyon lemaradva az első osztály kieső zónájától. Ilyen esetekben megfontolásra javasoljuk a kiesők számának növelését vagy pótselejtezős rendszer bevezetését. Ez azért lehet hasznos, mert a még éppen bennmaradó csapatok sem igazán versenyképesek az első osztályban, viszont a kiesők számának növelése motiváló tényezőt jelenthet a középmezőny csapatainak is.

Ennek fordított esete, ha a feljutók egyébként viszonylag jó mérkőzésenkénti pontszámot érnek el, de a magas bennmaradási küszöb miatt nem tudják megugrani a bennmaradáshoz szükséges teljesítményt. Hasonló tapasztalható Görögországban és Franciaországban. Ilyenkor indokolt lehet a kiesők számának csökkentése. A jobb bennmaradási esélyek kisebb kockázatot jelentenek a feljutók számára, ami jelentősebb ráfordításra motiválhatja őket a bennmaradás érdekében.

Ahhoz, hogy az újonc csapatok motivációit jobban megértsük, elvégeztük a kiesés és feljutás pénzügyi következményeit tárgyaló összehasonlító elemzést a magyar és az angol bajnokság között. A bérnövekedésböl az látszik, hogy a magyar élvonalban a feljutók általános célja az első osztályú tagság hosszabb távon történő megőrzése. Mivel az első és a másodosztály között nincs jelentős bevételkülönbség, egy esetleges kiesés következtében sem szenved a klub jelentős pénzügyi veszteséget. Angliában ezzel szemben inkább csak a feljutás kiharcolása a fó cél, a bennmaradás már másodlagos a kisebb piaccal rendelkező csapatok számára. Ez a következtetés egybeesik Noll [2002] és Goddard [2014] megfigyeléseivel, azonban az eredményeink a jelenség erősödését mutatják az 1990-es és 2000 -es évekhez képest. Ha az újonc csapatoknak nem éri meg a pénzügyi ráfordítás növelése a bennmaradás érdekében, az tovább mélyítheti az első és a másodosztály közti pénzügyi különbséget. Angliában a kiesőknek három évig fizetett kompenzációs közvetítői díj célja a másodosztály pénzügyi hátrányának csökkentése, ugyanakkor ennek eredményessége nem egyértelmü, mert gyengítheti az újoncok motivációját a bennmaradásra.

Azt gondoljuk, hogy az első osztályú csapatokra nehezedő nyomás és az újonc csapatok teljesítményének elemzése hozzájárulhat a bajnokságok pénzügyi és szabályrendszerének megfelelő kialakításához. A döntéshozóknak ezt figyelembe kell venniük a közvetítési és egyéb központi bevételek elosztásának tervezésekor. Az első osztályon belüli elosztás mellett az alsóbb osztályoknak juttatott források elősegíthetik a másodosztály pénzügyi hátrányának csökkentését. Ez több potenciális előnynyel járhat. Egyrészt kockázatmentesebbé teszi a feljutók beruházásait, másrészt változékonyabbá teszi az első osztályú csapatok körét, és így érdekesebb bajnoksághoz vezet. A nagyobb nyomás motiválja az első osztály középcsapatait, így javíthatja az első osztályon belüli versenyegyensúlyt is. Természetesen az első osztályban szereplö csapatok számára a bevételek átcsoportosítása veszteséget jelent, így fontos a költségek és hasznok körültekintő elemzése a ligák részéről. Ezeknek a mechanizmusoknak az empirikus vizsgálata és a sportklubok közgazdasági döntéseinek bővebb elemzése a nyílt hierarchikus ligarendszerben érdekes további kutatási irányt kínál. 


\section{Hivatkozások}

AndRefF, W. [2011]: Some comparative economics of the organization of sports: competition and regulation in north American vs. European professional team sports leagues. The European Journal of Comparative Economics, Vol. 8. No. 1. 3-27. o.

Buzzacchi, L.-Szymanski, S.-VAlletti, T. M. [2010]: Equality of Opportunity and Equality of Outcome: Open Leagues, Closed Leagues and Competitive Balance. Megjelent: Szymanski, S. (szerk): The Comparative Economics of Sport. Palgrave Macmillan, London, 174-197. o. https://doi.org/10.1057/9780230274273_5.

Celik, O. B. [2019]: Hazardous Attributes: Survival Analysis of Soccer Clubs in Turkish Super League. Spor Bilimleri Dergisi, Vol. 30. No. 1. 15-24. o. https://doi.org/10.17644/sbd.424518.

Chang, J.-Borrowman, L.-Frost, L. [2019]: Club survival in the English Premier League: What does it take to survive in the top flight? Megjelent: Wilson, J. K.-Pomfret, R. (szerk.): Historical Perspectives on Sports Economics. Edward Elgar Publishing, 167-184. o. https:// doi.org/10.4337/9781788977845.

Dherbecourt, J. B.-Drut, B. [2009]: Who will go down this year? The determinants of promotion and relegation in European soccer leagues. University of Paris Nanterre, EconomiX, No. 40.

FRICK, B.-WALLBRECHT, B. [2012]: Infant mortality of professional sports clubs? An organizational ecology perspective. Jahrbücher für Nationalökonomie und Statistik, Vol. 232. No. 3. 360-489. o. https://doi.org/10.1515/jbnst-2012-0312.

FÜRÉSz DiÁNA IVETT-RAPPAI GÁBOR [2018]: Koncentrációs mérőszámok „sportos” szerepkörben. Statisztikai Szemle, 96. évf. 10. sz. 949-972. o. https://doi.org/10.20311/stat2018.10.hu0949.

GodDARD, J. [2014]: The promotion and relegation system. Megjelent: Goddard, J.-Sloane, P. (szerk.): Handbook on the Economics of Professional Football. Edward Elgar Publishing, 23-40. o. https://doi.org/10.4337/9781781003176.00008.

Goossens, K. [2006]: Competitive balance in European football: Comparison by adapting measures: National measure of seasonal imbalance and top 3. Rivista di Diritto ed Economia dello Sport, Vol. 2. 77-122. o.

Gyimesi ANDRÁs [2020]: League Ranking Mobility Affects Attendance: Evidence from European Soccer Leagues. Journal of Sports Economics, Vol. 21. No. 8. 808-828. o. https://doi. org/10.1177/1527002520944451.

HaAn, M.-Koning, R. H.-Van Witteloostuijn, A. [2007]: Competitive balance in national European soccer competitions. Megjelent: Albert, J.-Koning, R. H. (szerk.): Statistical thinking in sports. Chapman \& Hall/CRC, https://doi.org/10.1201/9781584888697.ch4.

Hoenn, T.-Szymanski, S. [1999]: The americanization of European football. Economic Policy, Vol. 14. No. 28. 204-240. o. https://doi.org/10.1111/1468-0327.00048.

Humphreys, B. R. [2002]: Alternative measures of competitive balance in sports leagues. Journal of Sports Economics, Vol. 3. No. 2. 133-148. o. https://doi.org/10.1177/152700250200300203.

Hyndman, R. J.-FAn, Y. [1996]: Sample quantiles in statistical packages. American Statistician, Vol. 50. No. 4. 361-365. o. https://doi.org/10.2307/2684934.

Jasina, J.-RotThoff, K. [2012]: A model of promotion and relegation in league sports. Journal of Economics and Finance, Vol. 36. No. 2. 303-318. o. https://doi.org/10.1007/s12197-009-9120-4.

Kesenne, S. [2006]: Competitive balance in team sports and the impact of revenue sharing. Journal of Sport Management Vol. 20. No. 1. 39-51. o. https://doi.org/10.1123/jsm.20.1.39.

Krautmann, A. C.-Hadley, L. [2006]: Dynasties versus pennant races: Competitive balance in Major League Baseball. Managerial and Decision Economics, Vol. 27. No. 4. 287-292. o. https://doi.org/10.1002/mde.1260. 
Manasis, V.-Ntzoufras, I. [2014]: Between-seasons competitive balance in European football: Review of existing and development of specially designed indices. Journal of Quantitative Analysis in Sport, Vol. 10. No. 2. 1-14. o. https://doi.org/10.1515/jqas-2013-0107.

Michie, J.-Oughton, C. [2004]: Competitive balance in football: Trends and effects. The Sport Nexus, London.

NoLL, R. G. [2002]: The economics of promotion and relegation in sports leagues: The case of English football. Journal of Sports Economics, Vol. 3. No. 2. 169-203. o. https://doi.org $/ 10.1177 / 152700250200300205$.

Oberhofer, H.-Philippovich, T.-Winner, H. [2015]: Firm survival in professional sports: Evidence from the German football leauge. Journal of Sports Economics, Vol. 16. No. 1. 59-85. o. https://doi.org/10.1177/1527002512462582.

Pawlowski, T.-Breuer, C.-Hovemann, A. [2010]: Top clubs performance and the competitive situation in European domestic football competitions. Journal of Sports Economics, Vol. 11. No. 2. 186-202. o. https://doi.org/10.1177/1527002510363100.

Ross, S. F.-SZYMANSKI, S. [2002]: Open competition in league sports. Wisconsin Law Review, Vol. 2002. No. 3. 625-656. o.

SzYMANSKI, S. [2003]: The economic design of sporting contests. Journal of Economic Literature, Vol. 41. No. 4. 1137-1187. o. https://doi.org/10.1257/jel.41.4.1137.

Szymanski, S.-Valletti, T. M. [2010]: Promotion and relegation in sporting contests. Megjelent: Szymanski, S. (szerk.): The Comparative Economics of Sport. Palgrave Macmillan, London, 198-228. o. https://doi.org/10.1057/9780230274273_6.

\section{Függelék}

\section{F1. ábra}

Az újonc csapatok teljesítményének időbeli alakulása a belga, a dán, a holland, a norvég és a svéd első osztályú ligákban a DP20 mutató alapján, 10 éves mozgóátlagok, 1966/1967-2016/2017



Forrás: saját szerkesztés a www.worldfootball.net weboldal adatai alapján. 
F2. ábra

Az újonc csapatok teljesítményének időbeli alakulása a görög, az osztrák, a skót, az orosz, a portugál és a svájci első osztályú ligákban a DP20 mutató alapján, 10 éves mozgóátlagok, $1966 / 1967-2016 / 2017$



Forrás: saját szerkesztés a www.worldfootball.net weboldal adatai alapján.

F3. ábra

Az újonc csapatok teljesítményének időbeli alakulása a cseh, a horvát, a magyar, a román és a szerb első osztályú ligákban a DP20 mutató alapján, 10 éves mozgóátlagok, 1966/1967-2016/2017

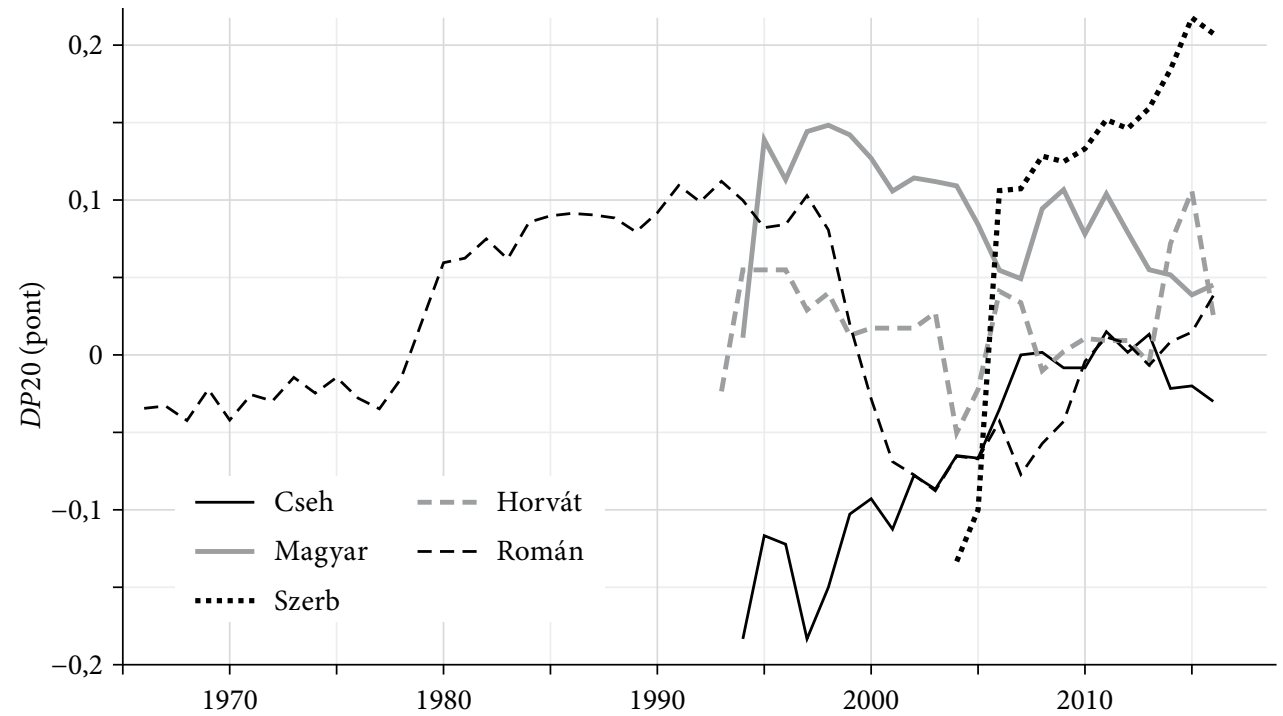

Forrás: saját szerkesztés a www.worldfootball.net weboldal adatai alapján. 